\title{
Type simple house walled CEB which efficient heat energy and embodied energy in Indonesia
}

\author{
Vincentius Totok Noerwasito ${ }^{a}$ \\ ${ }^{a}$ Department of Architecture Institut Teknologi Sepuluh Nopember, Kampus ITS Sukolilo, Surabaya 60111, Indonesia \\ E-mail address: totoknoerwasito@yahoo.com; vtonoer@arch.its.ac.id
}

\begin{abstract}
Efficient energy on heat energy and embodied energy in a simple house type in Indonesia needs to be observed. The type of house is very closely linked with the building area. It is necessary to know in order to determine the type of house by developers or for the government in terms of the energy. This energy efficiency is important because energy is a world problem that must be saved. The buildings in this study using Compressed Earth Block (CEB) wall material. CEB is a lowenergy building materials and local material. This material is a type of brick, but not through the process of burning. The research problem is the type of house which one has energy efficient? Because it is not always type with a small area will have energy efficient.

The method used was the optimization of the heat energy in this case the cooling load with embodied energy. The research variables was the building floor area is reflected in the type of building. Cooling load in a building was calculated for a year, simulating calculations of the cooling load performed by software Archipak. While the embodied energy calculations using the standard embodied energy per unit. The results showed that the type of building optimal heat energy and embodied energy is a type of building 70 or a building type with the largest area. Building that has a small embodied energy will produce heat energy which is small as well.
\end{abstract}

Keywords: dimple house; type; CEB; cooling load; embodied energy

\section{Background}

Simple house is needed by middle and low-class people. it is closely related to the price corresponding to the income from these communities. One factor that will greatly affect the price of the building is a building material. The used building materials, although relatively inexpensive must meet the requirements of environmental friendliness. Another important thing is the building materials must be energy efficient.

Cheap material is a building material that uses the raw materials from the surrounding area and the manufacturing process does not require a high energy production. While the production process of environmentally friendly building materials do not cause a lot of pollution to the surroundings and does not damage the surrounding natural resources.

Compressed earth block or CEB is the wall building materials. This material uses the local soil as a raw material. The production process of block is without use the burned process so that the production process does not require great energy. Therefore, CEB is a local building materials and environmentally friendly. CEB in this study is used as a wall of the building.

There are two important energies in building, mainly heat energy and embodied energy. Heat energy is the energy to cool down the heat inside the building caused by climate outside of building. Embodied energy is the 
energy used for the production of building materials from raw materials till finished materials. Good Energy in building is a low energy. Building materials greatly affect to heat energy and embodied energy.

The floor area of the building affects to the energy in the building. Building simple houses in Indonesia have a floor area of $36 \mathrm{~m}^{2}, 45 \mathrm{~m}^{2}, 54 \mathrm{~m}^{2}$ and $54 \mathrm{~m}^{2}$. Among these buildings need to know building that has energy efficient in terms of heat energy and embodied energy. The building area is determined by the number of bedrooms in the building.

The problem in this research is how to select a type of building that has heat energy and embodied energy efficient. As the model is a type of building 36, 45, 54 and $70 \mathrm{~m}^{2}$. The building uses a wall of Compressed Earth Block (CEB).

\section{Theory and methods}

Energy efficiency is an important thing to be considered in making the buildings. Therefore, the used of energy-efficient building materials is become important. The main objective is to use energy-saving materials to reduce the amount of energy produced by the building. Long-term energy costs of operating a building depends on the materials used in construction (Jong-Jin \& Brenda, 1998).

The study was conducted in the city of Surabaya. Surabaya has a minimum temperature of $21^{\circ} \mathrm{C}$ and a maximum temperature of $36^{\circ} \mathrm{C}$. The minimum humidity is $32 \%$ and maximum $98 \%$ humidity. Surabaya is located 7.2 LS.

This study calculates the heat energy in the form of cooling load for a year in any type of building. Calculations used software Archipak. Embodied energy calculations were also performed on all the buildings. Embodied energy calculations based on the multiplication of the area or volume of the material with the standard value per unit of embodied energy that already exists. Type of the buildings or the building floors area as a variable of the study.

Optimization is done to choose a type of building which has an optimal energy. Criteria of energy, the priorities are important in determining the type of building that is ideal. Optimization uses a chart with axes $\mathrm{X}$ and $\mathrm{Y}$, where $\mathrm{X}$ is cooling load while the $\mathrm{Y}$ axis is embodied energy. Type the ideal building is a building that is in accordance with a relatively low energy value and supported by energy criteria.

\section{Results and Discussion}

Compressed Earth block is a wall building material that has a shape and size that can be set by the user. The flexible form occurs because the production process material using molds, so that the shape and size can occur due to mold. The drying process this block without need direct sunlight, but using natural processes. Compressive strength which is owned as wall building material is $30 \mathrm{~kg} / \mathrm{cm}^{2}$. In this study the form used is a rectangular block while its dimensions are $21 \times 11 \times 5 \mathrm{~cm}$.

\subsection{Properties $C E B$}

Table 1 shows properties of compressed earth block. U-Value of Compressed Earth Block is higher than the red brick and concrete block. U-Value of red brick is $1.53 \mathrm{~W} / \mathrm{m}^{2} \mathrm{~K}$, while the brick is $2.84 \mathrm{~W} / \mathrm{m}^{2} \mathrm{~K}$. Embodied energy of compressed earth blocks is $750 \mathrm{MJ} / \mathrm{m}^{3}$. This embodied energy value is lower than embodied energy of red brick and concrete block. The embodied energy value of brick is $\mathrm{MJ} / \mathrm{m}^{3}$ and concrete block is $2350 \mathrm{MJ} / \mathrm{m}^{3}$. Because the value of properties embodied energy of compressed earth blocks against a red brick and concrete block better, then it was used as a wall in this study.

Table 1. Properties of compressed earth block.

\begin{tabular}{llcc}
\hline No & \multicolumn{1}{c}{ Properties } & value & unit \\
\hline 1 & U-value & 3.149 & $\mathrm{~W} / \mathrm{m}^{2} \mathrm{~K}$ \\
2 & Admitance & 5.481 & $\mathrm{~W} / \mathrm{m}^{2} \mathrm{~K}$ \\
3 & timelag & 5.1 & $\mathrm{Jam}$ \\
4 & Decrement factor & 0.582 & -
\end{tabular}




\begin{tabular}{lrrr}
5 & Embodied energy & 750 & $\mathrm{MJ} / \mathrm{m}^{3}$ \\
\hline Source archipak \& Embodied Energy Coefficients
\end{tabular}

\subsection{Cooling Load}

The value of the total cooling load for each type of building showed in Figure 1. The value of the total cooling load was lowest for the 36 type of building. The building has an area of the smallest. While the value of total cooling load is highest at 70 type building, this building has the largest floor area. In the Figure 1 there is a tendency that the floor area larger building will have a total cooling load is greater as well. This is indicated by an increase in the total value of the cooling load on any changes to the building floor area.

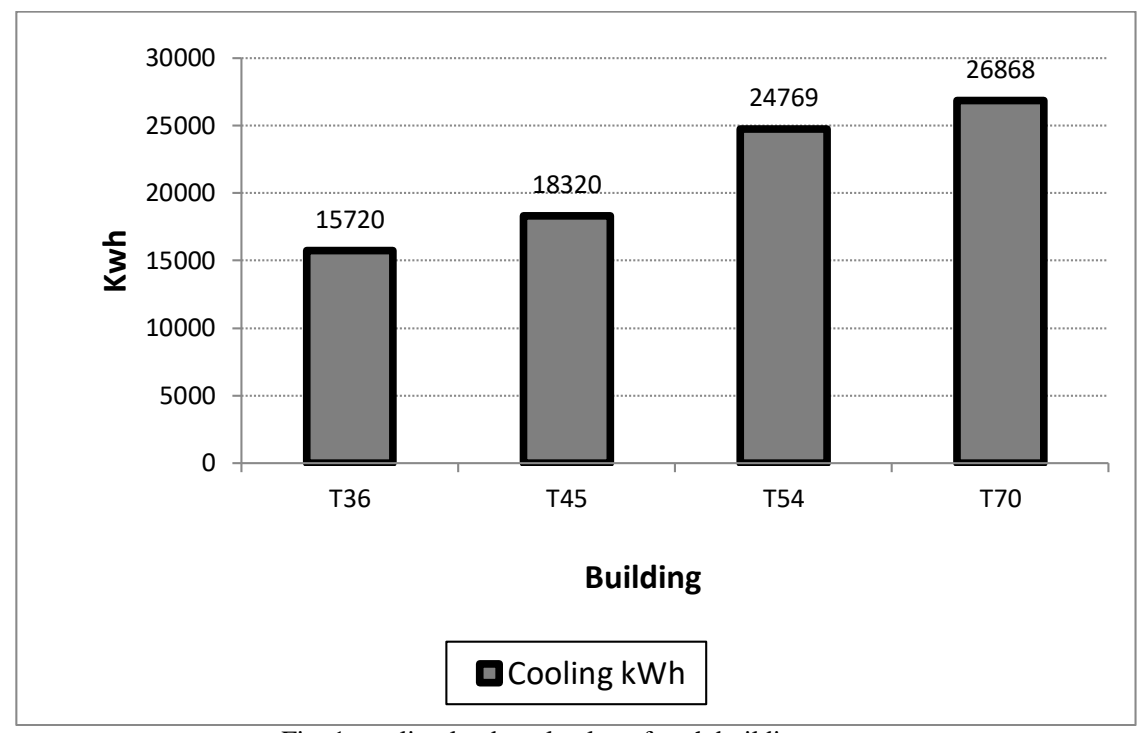

Fig. 1. cooling load total value of each building type.

To compare Cooling load on each type of buildings need to find value in the average cooling load, in this research the average cooling load is obtained from the value of cooling load per $\mathrm{m}^{2}$. That amount is the result of cooling load divided by the total floor building area. Figure 2 shows the different cooling load per $\mathrm{m}^{2}$ of each type.

The greatest cooling load contained in Type 36 and Type 54. Each of $437 \mathrm{Kwh} / \mathrm{m}^{2}$ and $459 \mathrm{Kwh} / \mathrm{m}^{2}$. Type 45 and 70 have lower cooling load per $\mathrm{m}^{2}$, respectively 407 and $384 \mathrm{Kwh} / \mathrm{m}^{2}$. In Figure 2 type 54 has highest cooling load in the building with a large floor area of relatively. While building with lowest cooling load per $\mathrm{m}^{2}$ is type 70 , the building has large floor area. Herein The value of cooling load per $\mathrm{m}^{2}$ does not showed no increase or decrease of cooling load. Further cooling load value used is the average cooling load or cooling load per $\mathrm{m}^{2}$. 


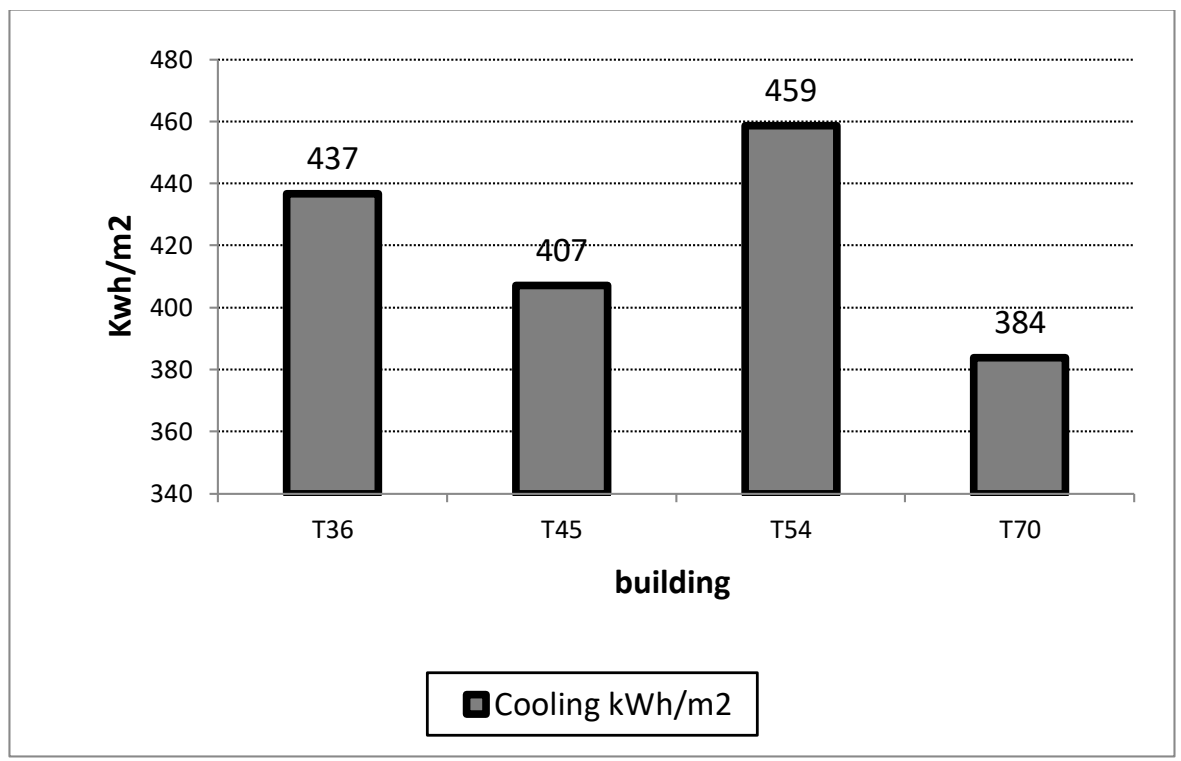

Fig. 2. Value cooling load per $\mathrm{m}^{2}$ of each type of building.

\subsection{Embodied Energy}

Embodied energy can be divided into two as the cooling load namely total embodied energy and average embodied energy or per $\mathrm{m}^{2}$. In Figure 3, the smallest total embodied energy is in buildings with the smallest area namely type 36 . While the highest total energy embodied owned by the largest floor area of the building namely the type 70. The total embodied energy of type 45 and 54 is following the floor area owned. There is a tendency that the total embodied energy is following the building floor area. Building with a relatively large floor area will have a high total energy embodied anyway.

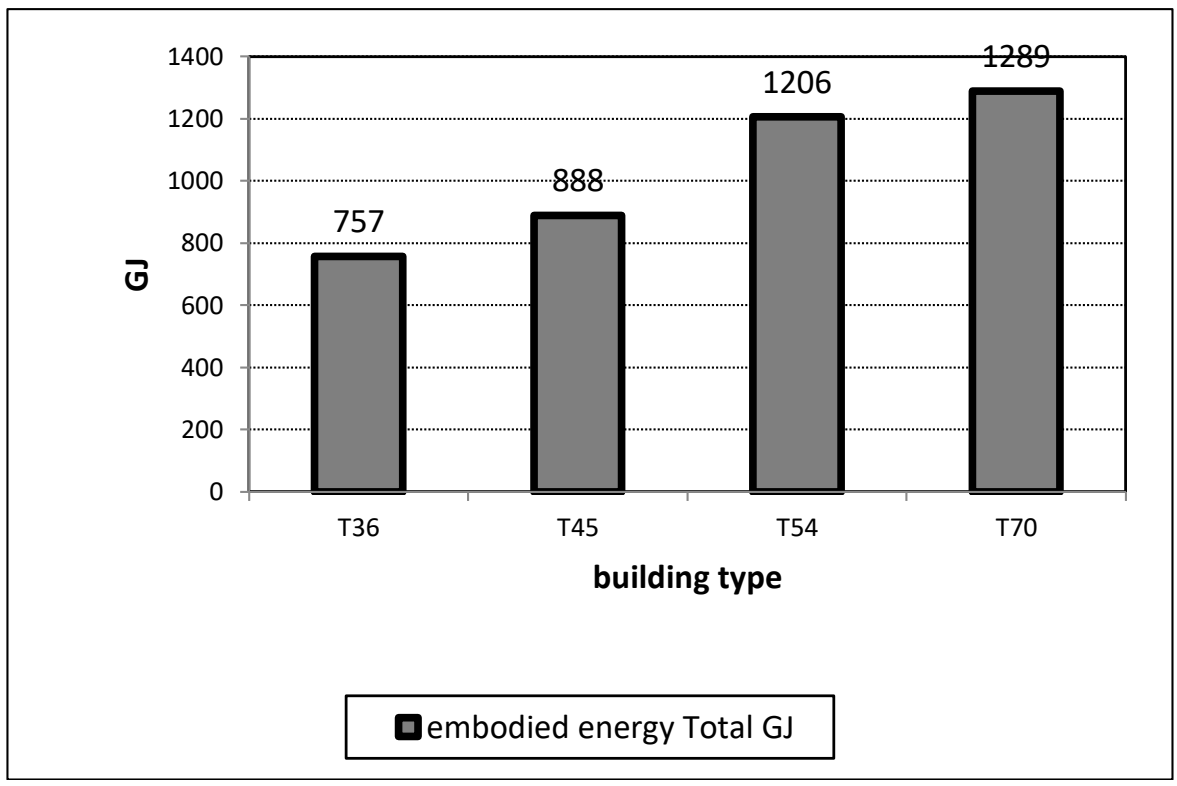

Fig. 3. Embodied energy total value of each type of building. 
Figure 4 shows the condition of the average energy embodied or embodied energy per $\mathrm{m}^{2}$ of each type of building. The building that has highest embodied energy per $\mathrm{m}^{2}$ is type 36 or buildings with a floor area of the smallest. This is in contrast with its total embodied energy. The same case is happened on the biggest story building type 70. This type has lowest embodied energy per $\mathrm{m}^{2}$ among other types. While the type 45 has a total embodied energy is higher than type 36 , but its embodied energy per $\mathrm{m} 2$ is lower than type 36 . This indicates that building with large floor area not always have the high average embodied energy.

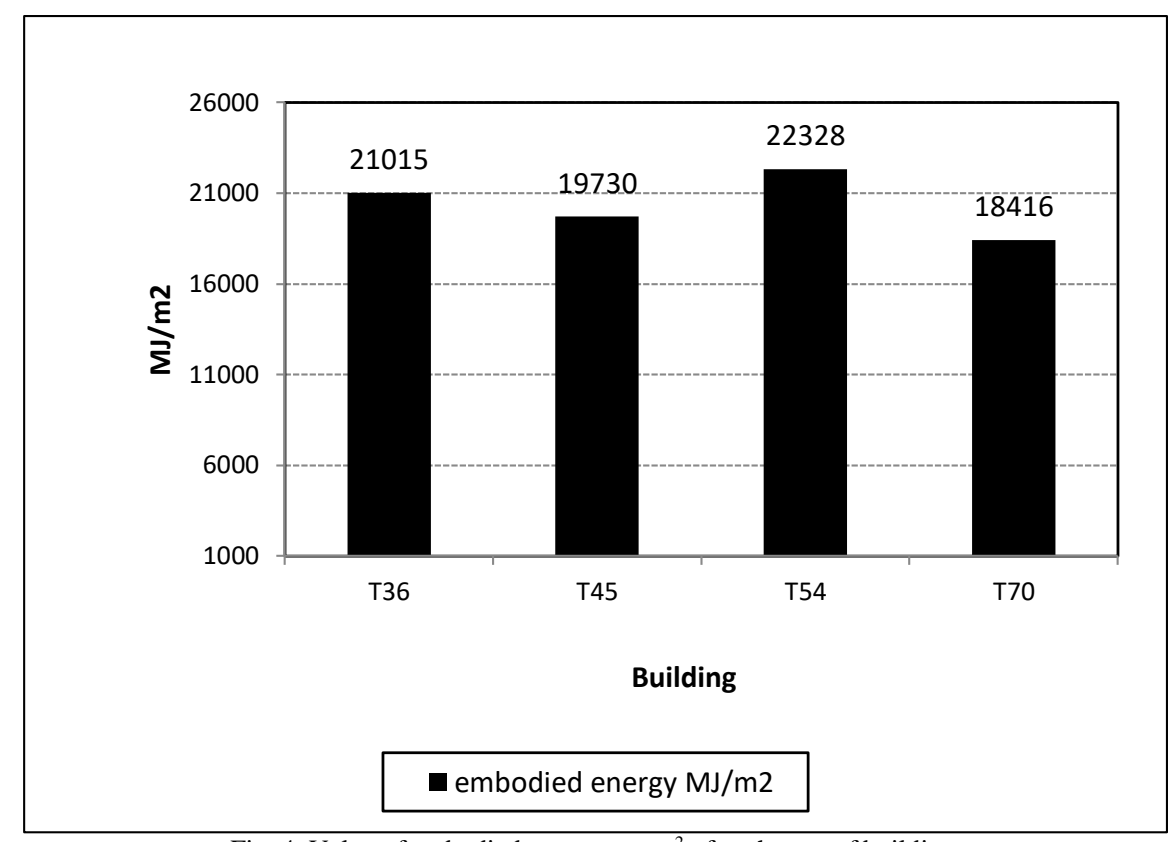

Fig. 4. Value of embodied energy per $\mathrm{m}^{2}$ of each type of building.

\subsection{Energy Optimization}

Energy optimization is done by combining the value cooling load per $\mathrm{m}^{2}$ and embodied energy per $\mathrm{m}^{2}$. In Figure 4 as the $\mathrm{x}$-axis is the cooling load per $\mathrm{m}^{2}$, while the $\mathrm{y}$-axis is the value embodied energy per $\mathrm{m}^{2}$. The average energy value of the cooling load and the embodied energy possessed all type serves as the dividing line between the energy high and the low. So there are areas of low energy and high energy zone.

The lower cooling load per $\mathrm{m}^{2}$ and embodied energy per $\mathrm{m}^{2}$ lower is the type of building 70 . Next type building with low energy is a type of building 45. The two types lie in the low energy region. Type of building 54 has the second highest energy beat type 36. Both are located in zone of high energy. 


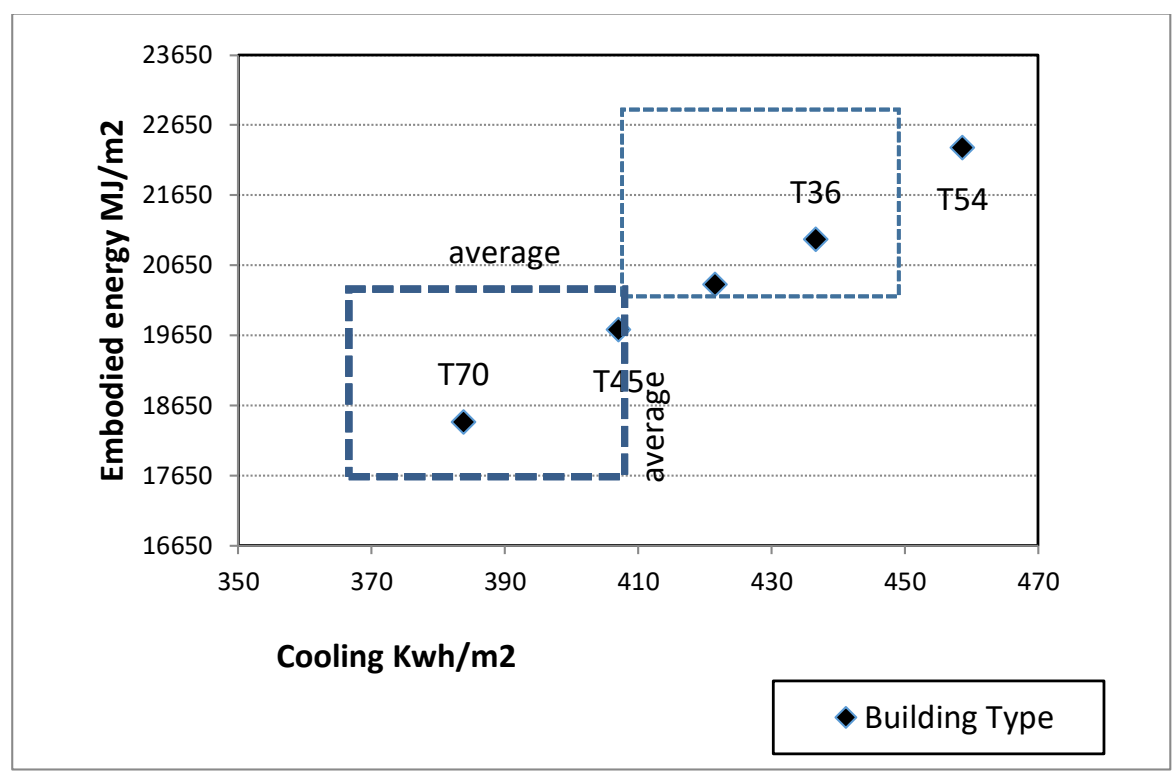

Fig. 4. Optimization between cooling load and embodied energy of the building type.

Determining the type of building that is selected based on appropriate consideration. Embodied energy and cooling load is an important energy in the building. In this study the cooling load is more important than the embodied energy, therefore the cooling load becomes the main priority. So that determined the ratio between the cooling load and embodied energy is $60 \%$ and $40 \%$.

Calculations score on each type building is determined by the score and percentage. Value percentage score obtained by multiplying the score with percentage is determined, for example, embodied energy $40 \%$, cooling load $60 \%$. Total score determines the most optimal energy and building type that energy efficient. Score calculation table can be seen in Table 2 .

Table 2. Selection of the optimal type of building.

\begin{tabular}{|c|c|c|c|c|c|}
\hline \multirow{2}{*}{$\begin{array}{c}\text { Type } \\
\text { bangunan }\end{array}$} & \multicolumn{2}{|c|}{ embodied energy } & \multicolumn{2}{|c|}{ cooling load } & \multirow{2}{*}{$\begin{array}{c}\text { Score total } \\
100 \%\end{array}$} \\
\hline & score & $\begin{array}{l}\text { Persentase } \\
\text { score } 40 \%\end{array}$ & score & $\begin{array}{l}\text { Persentase } \\
\text { score } 60 \%\end{array}$ & \\
\hline T36 & 3 & 1.2 & 3 & 1.8 & 3.00 \\
\hline $\mathrm{T} 45$ & 2 & 0.8 & 2 & 1.2 & 2.00 \\
\hline T54 & 4 & 1.6 & 4 & 2.4 & 4.00 \\
\hline $\mathrm{T} 70$ & 1 & 0.4 & 1 & 0.6 & 1.00 \\
\hline \multicolumn{6}{|l|}{ Note } \\
\hline $\begin{array}{l}\mathrm{Ve} \\
\text { go }\end{array}$ & ood & $\begin{array}{l}3 \\
4\end{array}$ & & & \\
\hline
\end{tabular}

Table 2 presented graphically to observe the type of buildings that have the most optimum energy (See Figure 5). The picture inside the building Type 36 and type 54 had a score greatest energy. Score value the smallest is the type of building 70 . It shows that the most optimum energy building among 36 building types; 45 ; and 54 is a building type 70 . 


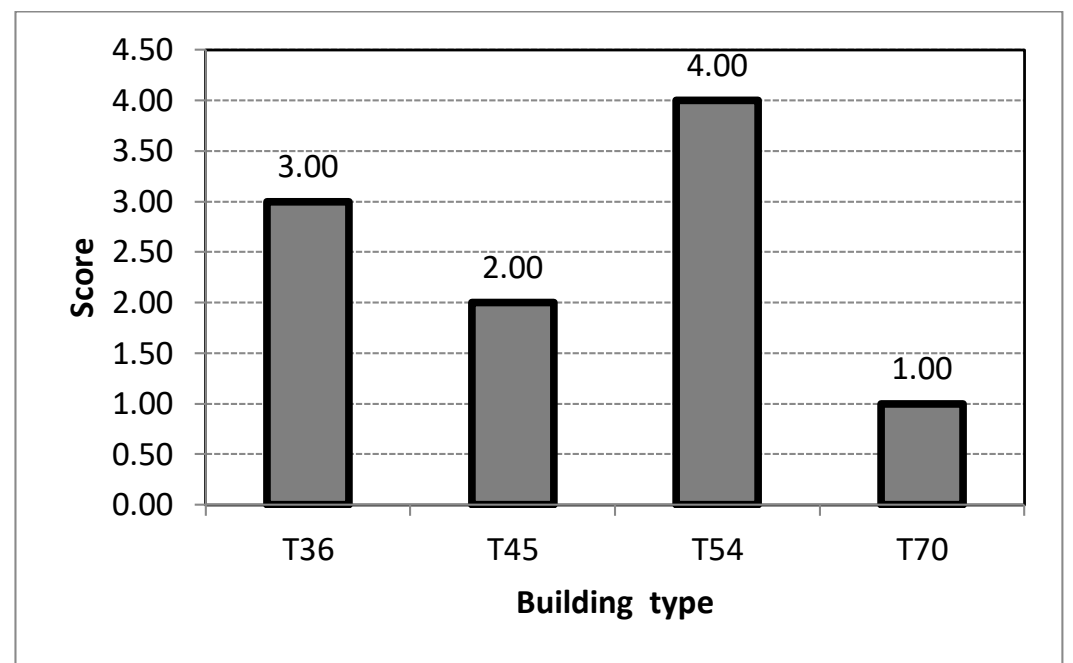

Fig. 5. Graph of score value of each type of building.

\section{Conclusion}

Compressed Earth Blocks have embodied energy per $\mathrm{m}^{2}$ lower than brick and concrete block concrete block. Besides, this material has a U-value is higher than the brick and concrete block. Compressed Earth Blocks is a local building material, since it can use soil material from the surrounding area.

The floor building area is not much greater effect on the cooling load of a building. In this study the small and mostly cooling load found in buildings with large floor area, namely types 70 and 45 . While the building has an area of relatively small have high cooling load. This indicates that the low cooling load is not always present in the building with a small floor area. Likewise, in a building with a large area is not always the produce cooling load is large.

Value embodied energy per $\mathrm{m}^{2}$ affected by floor area of the building. Value embodied energy per $\mathrm{m}^{2}$ inversely proportional to floor area of the building. The building with an area large has embodied energy per $\mathrm{m}^{2}$ is relatively low. In this study type 36 has embodied energy per $\mathrm{m}^{2}$ larger than type 70.

The optimal building has a cooling load and embodied energy has an area of a large building in this research is a type of building 70. The building is has greatest of building area, but it has the lowest energy. Type 36 is a spacious building with a small, but has a great energy. This shows that the building has a small floor area that is not always efficient in energy and building with large floor area is not always wasteful of energy.

There is a tendency that the buildings that have low embodied energy per $\mathrm{m}^{2}$ will produce the cooling load is low; or vice versa.

\section{References}

Jong-Jin, K., \& Brenda, R. (1998). Introduction to Sustainable Design Sustainable Architecture Module: Introduction to Sustainable Design. National Pollution Prevention Center for Higher Education. 